ORIGINAL ARTICLE

\title{
In vitro and in vivo activity of a hypotoxic copper(I) complex against dermotropic Leishmania species
}

\author{
Ana Flávia da Silva CHAGAS ${ }^{1,2, *}$, , Marina PORCHIA³, Thaís Pinto NASCIMENTO², Carolina Nunes Souza \\ CORREA ${ }^{2}$, Anny Maíza Vargas BRASIL ${ }^{1,2}$, Antonia Maria Ramos FRANCO ${ }^{2}$ \\ Universidade Federal do Amazonas, Programa de Pós-Graduação em Inovação Farmacêutica, Manaus, 69067-005, Amazonas, Brazil \\ 2 Instituto Nacional de Pesquisas da Amazônia, Laboratório de Leishmaniose e Doença de Chagas, Manaus, 69067-375, Amazonas, Brazil \\ 3 Istituto di Chimica della Materia Condensata e di Tecnologie per I'Energetica, Consiglio Nazionale delle Ricerche, Padova, 4-35127, Italy \\ * Corresponding author: chagas.afs@gmail.com.; (D) https://orcid.org/0000-0002-6677-9833
}

\begin{abstract}
Cutaneous leishmaniasis is a disease caused by protozoa of the genus Leishmania and, currently, the treatment of first choice is meglumine antimoniate. However, due to its limited effectiveness and high toxicity, it is necessary to seek new active principles for leishmaniasis treatment. Metal complexes are gaining importance due to their effectiveness and low toxicity. In this context, the present study aimed to evaluate the in vitro and in vivo antileishmanial activity of the hypotoxic copper(I) complex $\left[\mathrm{HB}(\mathrm{pz})_{3}\right] \mathrm{Cu}(\mathrm{PCN})$. Four dermotropic species of Leishmania were tested with the metal complex and its effectiveness was determined through parasitic viability and infectivity rate, and cytotoxicity was determined using a redox dye (resazurin). For the in vivo tests, hamsters were infected and the lesions treated with a formulated ointment containing the complex, the effectiveness of which was assessed by measuring the diameter of the inoculum/snout location and determining the parasitic load. The results demonstrated moderate toxicity in murine macrophages and human monocytes and better efficacy in Leishmania (V.) braziliensis when compared to the other species tested, with a 50\% reduction in the viability of promastigote and amastigote forms (in vitro). General data from daily topical treatment for up to 30 days showed low efficacy for reducing lesions, and no clinical and parasitological cure was observed in the experimental animals. Thus, the $\left[\mathrm{HB}(\mathrm{pz})_{3}\right] \mathrm{Cu}(\mathrm{PCN})$ complex proved to be promising in in vitro studies against $L$. (V.) braziliensis, and should be further tested in new formulations and new experimental treatment schemes.
\end{abstract}

KEYWORDS: leishmaniasis, treatment, metallic complex, antileishmanial activity

\section{Atividade in vitro e in vivo de um complexo de cobre(I) hipotóxico contra espécies dermotrópicas de Leishmania}

\section{RESUMO}

A leishmaniose cutânea é uma doença causada por protozoários do gênero Leishmania e, atualmente, o tratamento de primeira escolha é o antimoniato de meglumina. Porém, devido à sua eficácia limitada e alta toxicidade, é necessário buscar novos princípios ativos para o tratamento da leishmaniose. Os complexos metálicos vêm ganhando importância devido à sua eficácia e baixa toxicidade. Nesse contexto, o presente estudo teve como objetivo avaliar a atividade leishmanicida in vitro e in vivo do complexo hipotóxico de cobre $(\mathrm{I})\left[\mathrm{HB}(\mathrm{pz})_{3}\right] \mathrm{Cu}(\mathrm{PCN})$. Quatro espécies dermotrópicas de Leishmania foram testadas com o complexo metálico e sua eficácia foi determinada através da viabilidade parasitária e taxa de infectividade, e a citotoxicidade foi determinada com um corante redox (resazurina). Para os testes in vivo, hamsters foram infectados e as lesóes foram tratadas com uma pomada formulada contendo o complexo. A eficácia foi avaliada medindo o diâmetro do inóculo/focinho e determinando a carga parasitária. Os resultados demonstraram toxicidade moderada em macrófagos murinos e monócitos humanos e melhor eficácia em Leishmania (V.) braziliensis quando comparada às demais espécies testadas, com redução de 50\% na viabilidade das formas promastigotas e amastigotas (in vitro). Os dados gerais do tratamento tópico diário por até 30 dias mostraram baixa eficácia na redução das lesôes, e nenhuma cura clínica e parasitológica foi observada nos animais experimentais. Portanto, o complexo $\left[\mathrm{HB}(\mathrm{pz})_{3}\right] \mathrm{Cu}(\mathrm{PCN})$ mostrou-se promissor em estudos in vitro contra L. (V.) braziliensis, devendo ser empregado em novas formulaçóes e novos esquemas de tratamento experimental.

PALAVRAS-CHAVE: leishmaniose, tratamento, complexo metálico, atividade antileishmania 


\section{INTRODUCTION}

Cutaneous leishmaniasis (CL) is a neglected disease and endemic in more than 92 countries, with over $90 \%$ of cases occurring in the Americas (WHO 2021). Transmission is vectorial, and its etiological agents are the protozoans of the genus Leishmania (Blanco 2017). Currently, at least 20 species are known to be pathogenic to man and, among them, a total of seven dermotropic species are found in Brazil. Leishmania (Viannia) guyanensis, L. (V.) braziliensis and L. (Leishmania) amazonensis are highlighted in Brazil due to their wide distribution and the induction of different clinical manifestations (Teles et al. 2016).

In the treatment of CL, pentavalent antimonials are most commonly employed, and pentamidine and amphotericin B are the drugs of second choice. Considering that these drugs have low efficacy due to parasitic diversity and resistance, high toxicity, and require a long and painful treatment, the search for new active principles with more effective action is warranted (Bastos et al. 2016; Brasil 2017).

In this context, metal complexes are prominent candidates, as they have unique properties, such as the ability to bypass resistance mechanisms and the possibility of being used in multi-target molecule design (compounds that can reach the target organism by at least two independent mechanisms) (Ong et al. 2019). Transition metals have peculiar characteristics that favor performance in biological functions, and copper $(\mathrm{Cu})$ is a biologically active transition metal (Krupanidhi et al. 2008).

Copper(I/II) compounds have been widely evaluated for their anti-tumor properties (e.g. Tisato et al. 2016; Hussain et al. 2019; Porchia et al. 2020), and have also been proposed for other therapeutic purposes, e.g. as antimalarial agents (Tapanelli et al. 2017). Several studies have investigated the activity of copper complexes in different oxidation states, and $\mathrm{Cu}(\mathrm{II})$ complexes have shown promising results in vitro against Leishmania spp. (Maffei et al. 2009; Portas et al. 2012; Arndt et al. 2017; Méndez-Arriaga et al. 2018). Copper is physiologically internalized by eukaryotic cells as copper(I), however, only Navarro et al. (2003) and Saeed et al. (2018) have shown the activity of copper(I) complex against promastigote forms.

The copper(I) complex $\left[\mathrm{HB}(\mathrm{pz})_{3}\right] \mathrm{Cu}(\mathrm{PCN})$ presented in vitro and in vivo cytotoxic activity in cancer cells (Gandin et al. 2014). Considering that anticancer drugs can exert antileishmanial activity (Keighobadi et al. 2018), the aim of this study was to evaluate the in vitro and in vivo antileishmanial activity of the $\left[\mathrm{HB}(\mathrm{pz})_{3}\right] \mathrm{Cu}(\mathrm{PCN})$ complex in Leishmania spp., and the effects of cytotoxicity on murine peritoneal macrophages and human monocytes.

\section{MATERIALS AND METHODS}

\section{Substance}

The target molecule in this study was the hypotoxic copper(I) $\left[\mathrm{HB}(\mathrm{pz})_{3}\right] \mathrm{Cu}(\mathrm{PCN})$ complex, where $\mathrm{PCN}=$ triscyanomethylphosphine and $\mathrm{HBPz}_{3}=$ trispyrazolylborate anion. This compound was synthesized and purified as previously described by Gandin et al. (2014), and the meglumine antimoniate (Glucantime; Sanofi-Aventis, São Paulo, Brazil) was used as a drug of standard choice (Brasil 2017).

\section{Parasites}

The strains used in this study were Leishmania (Leishmania) amazonensis (IFLA/BR/1967/PH8), Leishmania (Viannia) guyanensis (MHOM/BR/1975/M4147), Leishmania (Viannia) braziliensis (MHOM/BR/1975/2904) and Leishmania (Viannia) naiff (MDAS/BR/1979/M5533), obtained from the Roswell Park Memorial Institute (RPMI 1640 - Sigma Chemical Co. St. Louis, USA), supplemented with $10 \%$ inactivated fetal bovine serum - FBSi (LGC Biotecnologia,

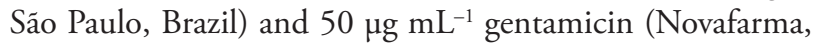
Brazil) - complete RPMI medium, incubated at $25^{\circ} \mathrm{C}$ and kept in the Laboratory of Leishmaniasis and Chagas Disease at Instituto Nacional de Pesquisas da Amazônia (INPA), Manaus, Brazil.

\section{In vitro biological assay}

Murine peritoneal macrophages and human monocytes (primary culture/individual assays) were grown in 96-well plates $\left(10^{5}\right.$ cells $\left.\mathrm{mL}^{-1}\right)$ in complete RPMI medium, in an incubator containing 5\% $\mathrm{CO}_{2}$ (Form Series II Water Jacket $\mathrm{CO}_{2}$ Incubator, Thermo Scientific, USA) at $37^{\circ} \mathrm{C}$, for $24 \mathrm{~h}$. The cells were treated with different concentrations of the copper(I) complex $(0.16,0.08,0.04,0.02$ and $0.01 \mathrm{mM})$ or Glucantime (33.00, 16.50, 8.25, 4.12 and $2.06 \mathrm{mM})$. Wells without cells were kept blank and wells with cells though without treatment were maintained as controls. Cell viability was assessed using resazurin sodium salt (Sigma Aldrich $^{\text {TM }}$, USA) during 24, 48 and $72 \mathrm{~h}$ with the addition of $10 \mu \mathrm{L}$ of stock solution of resazurin sodium salt $\left(4 \mathrm{mg} \mathrm{mL}^{-1}\right.$ in phosphate buffered saline) in each well and the plates incubated again for another $12 \mathrm{~h}$ at $37^{\circ} \mathrm{C}$. The absorbance was read on a spectrophotometer (Elx800 ${ }^{\mathrm{TM}}$, BIO-TEK, USA) at a wavelength of $590 \mathrm{~nm}$. The data were normalized according to the following formula: \% of survival = Abs. Sample-Abs. blank/bs. control-Abs. blank $\times 100$ (Nascimento et al. 2019).

\section{Biological assays in promastigote forms}

Promastigotes were grown in 96-well plates $\left(2 \times 10^{6}\right.$ promastigotes $\mathrm{mL}^{-1}$ ) in complete RPMI medium and treated over 24, 48 and $72 \mathrm{~h}$ with different concentrations of the copper(I) complex $(0.16,0.08,0.04,0.02$ and $0.01 \mathrm{mM})$ or Glucantime $(33.00,16.50,8.25,4.12$ and $2.06 \mathrm{mM})$. 
Wells with untreated promastigotes were maintained as controls. Biological activity was determined by quantifying viable promastigotes in a hemocytometer, using an optical microscope (Eclipse E200, Nikon, Japan) with 400x magnification. The data were expressed as half of the maximum inhibitory concentration $\left(\mathrm{IC}_{50}\right)$ and the selectivity index (SI) was calculated from the ratio between cytotoxicity to human monocytes $\left(\mathrm{CC}_{50}\right)$ and the activity against promastigotes $\left(\mathrm{IC}_{50}\right)$ (Comandolli-Wyrepkowki et al. 2017).

\section{Biological tests in amastigote forms}

The evaluation of in vitro antileishmanial activity of the copper(I) complex in amastigotes was performed as described by Nascimento et al. (2019), with some adaptations. Murine peritoneal macrophages and human monocytes (individual assays) were infected with promastigotes of each of the Leishmania species in a $10: 1$ ratio $\left(10^{6}\right.$ parasites: $10^{5}$ cells $)$ on glass coverslips in 24-well plates containing complete RPMI culture medium, which was subsequently placed in an incubator at $37^{\circ} \mathrm{C}$ and $5 \% \mathrm{CO}_{2}$ for up to $2 \mathrm{~h}$. After this time, the infected cells were maintained either in complete RPMI medium (control) or RPMI medium containing different concentrations of the copper(I) complex $(0.16,0.08,0.04$ and $0.02 \mathrm{mM}$ ) and Glucantime $(33.00,16.50,8.25,4.12$ and $2.06 \mathrm{mM}$ ) for 24,48 and $72 \mathrm{~h}$ at $37^{\circ} \mathrm{C}$ and $5 \% \mathrm{CO}_{2}$. Then, the coverslips were fixed and stained every $24 \mathrm{~h}$ using the Quick Panoptic method (Laborclin', Brazil) and analyzed using optical microscopy. The percentage of infected cells was estimated by randomly counting 100 infected and uninfected cells on each slide (Comandolli-Wyrepkowki et al. 2017).

\section{Preparation of topical formulation for in vivo biological assays}

The ointment was prepared with $0.02 \%$ butyl hydroxytoluene, propylene glycol, 30\% anhydrous lanolin and solid petroleum jelly. Then, $0.5 \mathrm{mg}$ of copper(I) complex in $80 \mathrm{mg}$ ointment was added. Base ointment without copper(I) complex was used as a placebo control.

\section{In vivo biological assay}

Ninety male golden hamsters (Mesocricetus auratus), weighing $120 \mathrm{~g}$ and aged 60 days, were kept in the Central Animal Facility at INPA, with water and food ad libitum, in rooms with controlled photoperiod and temperature (22$24^{\circ} \mathrm{C}$ ). The ninety animals were divided into three groups of thirty animals for the experimental infection procedure. From each group of 30 animals, 24 were infected by one of the species of Leishmania studied, and the other six animals were not infected and constituted the control group. In the hamster's snout, $0.1 \mathrm{~mL}^{-1}$ of sterile saline $(0.9 \%)$ containing promastigotes $\left(10^{6}\right.$ promastigotes $\left.\mathrm{mL}^{-1}\right)$ in stationary phase was injected intradermally. After the lesion appeared, at variable times, according to the species of Leishmania, the animals were randomly divided into five groups (six animals per group) and treated once daily, for 25 to 30 days, in the following manner: I) uninfected and untreated; II) infected and untreated; III) infected and treated with base ointment (placebo); IV) infected and treated with Glucantime 20 $\mathrm{mg}\left(\mathrm{Sb}^{5}\right) \mathrm{kg} \mathrm{day}^{-1}$ intramuscularly; V) infected and treated with ointment containing $0.5 \mathrm{mg}$ of the copper(I) complex. We did not perform in vivo tests with $L$. (V.) naiffi due to the lack of macroscopically visible skin lesions in the hamsters.

To evaluate the treatments, the total lesion volume was determined on a weekly basis by measuring the snout with a digital caliper $\left(\mathrm{MTX}^{\circ}\right)$, the lesions were photo-documented (SM-G570M/DS, Samsung, South Korea) for morphological analysis (Comandolli-Wyrepkowki et al. 2017) and the animals were weighed.

\section{Parasitological and hematological evaluation of treatment}

All animals used in the experiment were euthanized through intramuscular injection of ketamine $\left(10 \mathrm{mg} \mathrm{kg}^{-1}\right)$ and xylazine $\left(90 \mathrm{mg} \mathrm{kg}^{-1}\right)$. After the euthanasia procedure, the liver, spleen and kidneys were removed and weighed on a precision scale. Skin tissue fragments from the inoculated site, as well as viscera tissue (liver, spleen and kidneys), were excised aseptically and cultured in Novy-MacNeal-Nicolle (NNN) medium for up to 20 days at $25^{\circ} \mathrm{C}$. The result was considered positive when at least one form of the parasite was isolated from the culture medium (Comandolli-Wyrepkowki et al. 2017).

Tissue samples from the lesion area on the snout of each animal were imprinted on glass slides. These were fixed and stained using the Quick Panoptic method and analyzed under optical microscopy. The percentage of infected cells was estimated by randomly counting 25 fields in each coverslip (Comandolli-Wyrepkowki et al. 2017).

Blood smears were prepared on slides and, subsequently, the biological material was fixed and stained using the Quick Panoptic method. The leukocyte cells were differentiated and quantified by counting 100 cells per slide at 400x magnification.

\section{Statistical analysis}

$\mathrm{IC}_{50}$ and $\mathrm{CC}_{50}$ were obtained through linear regression using the number of living cells A one-way ANOVA followed by Tukey's test was used to assess the significance of the differences between the groups of the in vivo biological assay, at the 5\% significance level. All statistical analyses was performed using the GraphPad Prism program version 6.0 for Windows (GraphPad Software, San Diego, CA).

\section{Ethical aspects}

The in vitro tests were approved by the Ethics Committee on the Use of Animals of INPA (CEUA/INPA authorization \# 023/2020 - 01280.000455/2020-41) and by the Research 
Ethics Committee of Universidade Federal do Amazonas (CAAE authorization \# 29406319.2.0000.5020). The in vivo tests were approved by the Ethics Committee on the Use of Animals of INPA (CEUA/INPA authorization \# 059/2018 - 01280.001884/2018-11).

\section{RESULTS}

In the cytotoxicity evaluation, the copper(I) complex showed moderate toxicity for murine peritoneal macrophages and human monocytes, with cell viability above $80 \%$ and $75 \%$, respectively. The $\mathrm{CC}_{50}$ of the copper(I) complex for both cell types was $>0.4 \mathrm{mM}$ during the incubation period. Cell viability was $80 \%$ in the group treated with Glucantime ${ }^{\circ}$, and
$85 \%$ in the group treated with dimethyl sulfoxide (DMSO), and $86 \%$ and $93 \%$ in murine peritoneal macrophages and human monocytes, respectively.

The in vitro experiments carried out with promastigotes incubated during 24, 48 and $72 \mathrm{~h}$, the copper(I) complex showed a lower $\mathrm{IC}_{50}$ in $L$. (V.) braziliensis promastigotes in $72 \mathrm{~h}(0.071 \mathrm{mM})$, followed by $L(V$.$) guyanensis in 48 \mathrm{~h}$ $(0.086 \mathrm{mM}), L$. (V.) naiffi in $72 \mathrm{~h}(0.096 \mathrm{mM})$ and $L$. (L.) amazonensis in $72 \mathrm{~h}(0.186 \mathrm{mM})$ and SI $>20$ in $72 \mathrm{~h}$ for all the tested species (Table 1).

There was no significant difference in the parasitic viability of $L$. (L.) amazonensis promastigotes (Figure 1a), however, the concentrations of 0.16 and $0.08 \mathrm{mM}$ of the copper(I) complex
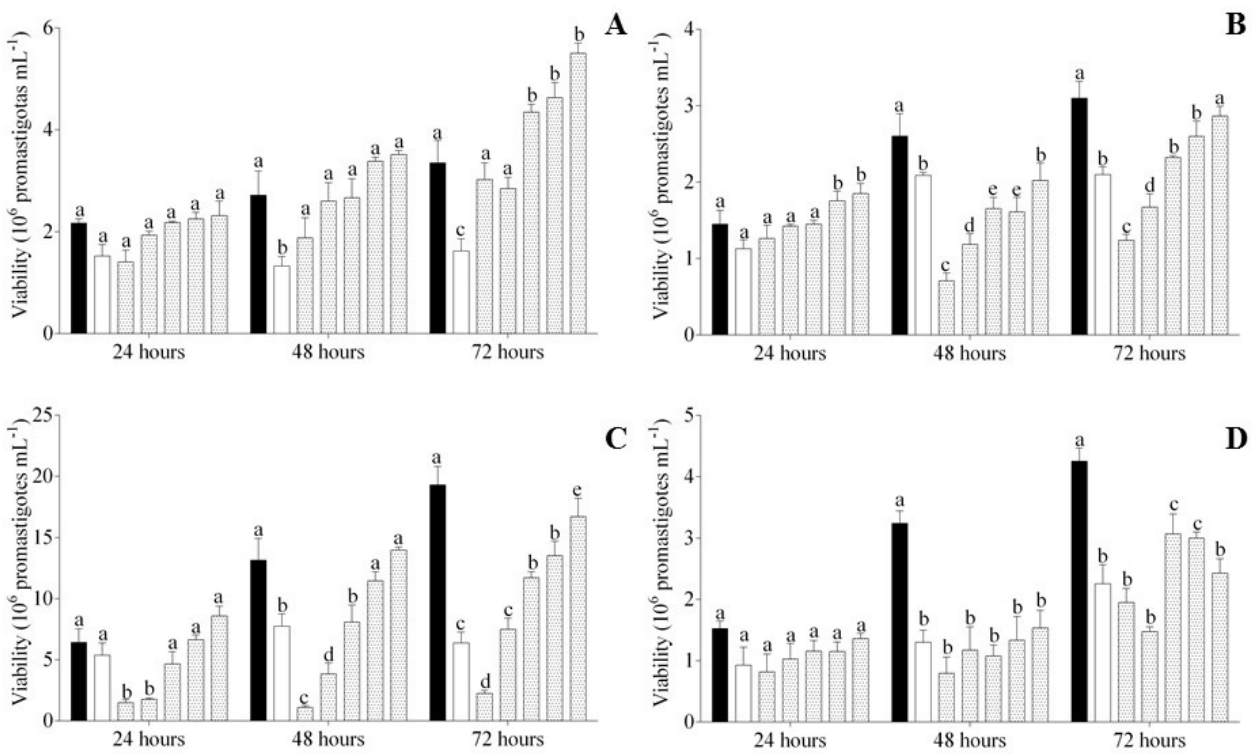

Figure 1. Parasitic viability of promastigote forms of Leishmania (L.) amazonensis (A); L. (V.) guyanensis (B); L. (V.) braziliensis (C); and L. (V.) naiff (D). Untreated promastigotes (black columns), promastigotes treated with $33 \mathrm{mM}$ Glucantime" (white columns) and 0.16, 0.08, 0.04, 0.02 and $0.01 \mathrm{mM}$ copper(I) complex (dotted columns). Columns represent the mean and bars the standard deviation. Different letters within periods indicate significant difference according to the Tukey test $(p<0.05)$.

Table 1. Inhibitory concentration at $50 \%\left(\mathrm{IC}_{50} \mathrm{mM} \pm \mathrm{SD}\right)$ and selectivity index (SI) of $\left[\mathrm{HB}(\mathrm{pz})_{3}\right] \mathrm{Cu}(\mathrm{PCN})$ and Glucantime ${ }^{\oplus}$ in promastigote forms of Leishmania spp.

\begin{tabular}{|c|c|c|c|c|c|}
\hline \multirow{2}{*}{ Species } & \multirow{2}{*}{$\begin{array}{c}\text { Period } \\
\text { (h) }\end{array}$} & \multicolumn{2}{|c|}{$\left[\mathrm{HB}(\mathrm{pz})_{3}\right] \mathrm{Cu}(\mathrm{PCN})$} & \multicolumn{2}{|c|}{ Glucantime $^{\circledast}$} \\
\hline & & $\mathrm{IC}_{50}(\mathrm{mM})$ & SI & $\mathrm{IC}_{50}(\mathrm{mM})$ & $\mathrm{SI}$ \\
\hline \multirow{3}{*}{ L. (L.) amazonensis } & 24 & $0.216 \pm 0.14$ & 2.20 & $38.15 \pm 0.15$ & 10.32 \\
\hline & 48 & $0.213 \pm 0.25$ & 3.71 & $26.13 \pm 0.33$ & 37.42 \\
\hline & 72 & $0.186 \pm 0.40$ & 20.64 & $18.08 \pm 0.21$ & 85.45 \\
\hline \multirow{3}{*}{ L. (V.) guyanensis } & 24 & $0.300 \pm 0.10$ & 1.59 & $46.28 \pm 0.09$ & 8.51 \\
\hline & 48 & $0.086 \pm 0.23$ & 0.08 & $93.12 \pm 0.08$ & 10.50 \\
\hline & 72 & $0.117 \pm 0.20$ & 34.90 & $42.8 \pm 0.47$ & 36.10 \\
\hline \multirow{3}{*}{ L. (V.) braziliensis } & 24 & $0.094 \pm 0.50$ & 5.07 & $46.23 \pm 0.42$ & 8.52 \\
\hline & 48 & $0.078 \pm 0.83$ & 9.71 & $31.34 \pm 0.62$ & 31.19 \\
\hline & 72 & $0.071 \pm 1.03$ & 54.08 & $17.24 \pm 0.68$ & 89.62 \\
\hline \multirow{3}{*}{ L. (V.) naiffi } & 24 & $0.173 \pm 0.19$ & 2.75 & $40.71 \pm 0.22$ & 9.67 \\
\hline & 48 & $<0.01 \pm 0.53$ & 75.8 & $25.96 \pm 0.17$ & 37.66 \\
\hline & 72 & $0.096 \pm 0.29$ & 40 & $24.26 \pm 0.36$ & 63.68 \\
\hline
\end{tabular}


induced a significant decrease in parasitic viability in $L$. (V.) guyanensis $(\mathrm{F}=129.9, \mathrm{p}<0.0001)$ and $L$. (V.) naiffi $(\mathrm{F}=174.1$, $\mathrm{p}<0.0001)$ relative to the negative control, with a reduction $>$ $50 \%$ in 48 and $72 \mathrm{~h}$ (Figure 1b,d). In L. (V.) braziliensis, this reduction is observed throughout the incubation period, with significant differences from the negative control $(\mathrm{F}=162.1$, $\mathrm{p}<0.0001)$. The copper(I) complex showed efficacy similar to Glucantime and a concentration-dependent effect for all species (Figure 1c).

In the in vitro experiments with amastigotes incubated, the copper(I) complex showed promising results against $L$. (V.) braziliensis and $L$. ( $L$.) amazonensis over $72 \mathrm{~h}\left(\mathrm{IC}_{50}<0.02\right.$ $\mathrm{mM})$ and $L$. (V.) guyanensis over $24 \mathrm{~h}\left(\mathrm{IC}_{50}<0.081 \mathrm{mM}\right)$ in both cell models. For $L$. (V.) naiff, the tested concentrations were not effective in inhibiting amastigote forms $\left(\mathrm{IC}_{50}>0.16\right.$ $\mathrm{mM}$ ) (Table 2).

As observed in the promastigote forms, the copper(I) complex was more effective against $L$. (V.) braziliensis, and induced a $75 \%$ reduction in the infection rate of murine peritoneal macrophages $(\mathrm{F}=303.1, \mathrm{p}<0.0001)$ over the entire period of incubation. There was no significant difference from cells treated with Glucantime (Figure 2c). Similar results were observed for $L$. (L.) amazonensis, but only after 48 and $72 \mathrm{~h}$ (Figure 2a). In contrast, in $L$. (V.) guyanensis there was a significant reduction $(\mathrm{F}=53.2, \mathrm{p}<0.0001)$ in the number of infected murine peritoneal macrophages only at $24 \mathrm{~h}$ (Figure

Table 2. Inhibitory concentration (I $\mathrm{C}_{50} \mathrm{mM} \pm \mathrm{SD}$ ) of the complex $\left[\mathrm{HB}(\mathrm{pz})_{3}\right] \mathrm{Cu}(\mathrm{PCN})$ and Glucantime ${ }^{\circledast}$ in amastigotes of Leishmania spp. in murine peritoneal macrophages and human monocytes. SD = standard deviation.

\begin{tabular}{|c|c|c|c|c|c|}
\hline \multirow{2}{*}{ Species } & \multirow{2}{*}{$\begin{array}{c}\text { Period } \\
\text { (h) }\end{array}$} & \multicolumn{2}{|c|}{$\left[\mathrm{HB}(\mathrm{pz})_{3}\right] \mathrm{Cu}(\mathrm{PCN})$} & \multicolumn{2}{|c|}{ Glucantime $^{\oplus}$} \\
\hline & & Macrophages & Monocytes & Macrophages & Monocytes \\
\hline \multirow{3}{*}{ L. (L.) amazonensis } & 24 & $0.321 \pm 4.24$ & $>0.16$ & $12.40 \pm 3.00$ & $8.73 \pm 5.65$ \\
\hline & 48 & $<0.02$ & $0.107 \pm 7.07$ & $<4 \pm 3.00$ & $75.75 \pm 5.65$ \\
\hline & 72 & $<0.02$ & $0.355 \pm 4.41$ & $2.09 \pm 2.47$ & $224 \pm 3.71$ \\
\hline \multirow{3}{*}{ L. (V.) guyanensis } & 24 & $0.081 \pm 4.06$ & $<0.2$ & $21.51 \pm 2.65$ & $2.07 \pm 3.61$ \\
\hline & 48 & $0.77 \pm 1.94$ & $0.43 \pm 5.74$ & $36.66 \pm 5.12$ & $147.87 \pm 5.65$ \\
\hline & 72 & $21.24 \pm 1.94$ & 0.2 & $78.54 \pm 3.18$ & $244.39 \pm 2.48$ \\
\hline \multirow{3}{*}{ L. (V.) braziliensis } & 24 & $<0.02$ & $0.40 \pm 4.59$ & $4.35 \pm 7.24$ & $330.63 \pm 7.77$ \\
\hline & 48 & $<0.02$ & $0.94 \pm 4.24$ & $<4$ & $<4$ \\
\hline & 72 & $<0.02$ & $<0.02 \pm 3.42$ & $<4$ & $<4$ \\
\hline \multirow{3}{*}{ L. (V.) naiffi } & 24 & $0.31 \pm 3.53$ & $1.45 \pm 2.12$ & $>100 \pm 3.53$ & $81.99 \pm 4.66$ \\
\hline & 48 & $0.29 \pm 5.30$ & $3.84 \pm 0.96$ & $>100 \pm 3.53$ & $>100 \pm 1.23$ \\
\hline & 72 & $0.21 \pm 2.12$ & $5.1 \pm 0.86$ & $52.18 \pm 5.65$ & $>100 \pm 0.97$ \\
\hline
\end{tabular}

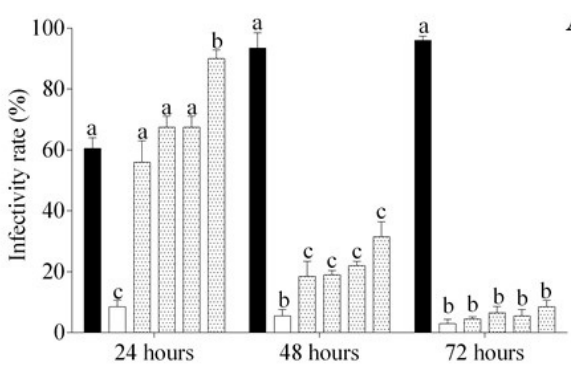

A
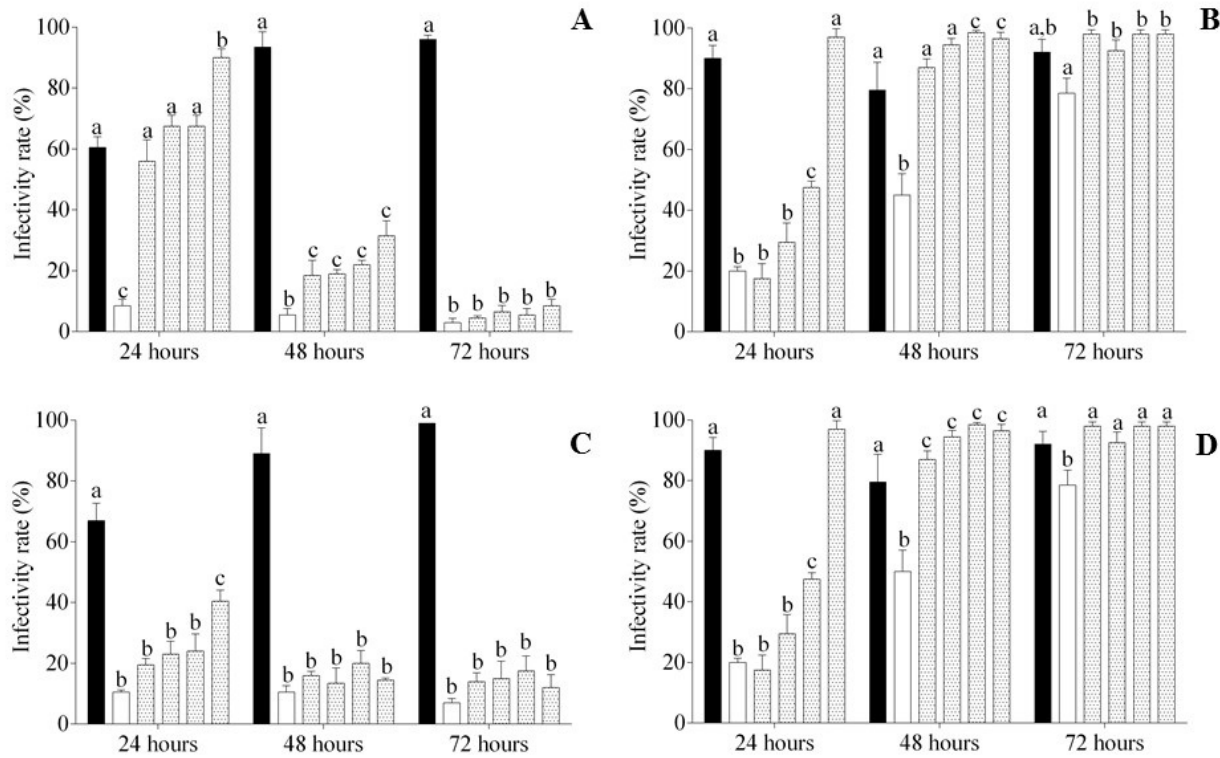

Figure 2. Infectivity rate of murine peritoneal macrophages infected by Leishmania (L.) amazonensis (A); L. (V.) guyanensis (B); L. (V.) braziliensis (C); and L. (V.) naiff (D).

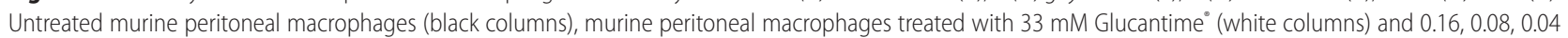
and $0.02 \mathrm{mM}$ copper(I) complex (dotted columns). Columns represent the mean and bars the standard deviation. Different letters within periods indicate significant differences according to the Tukey test $(p<0.05)$. 
2b) and in $L$. (V.) naiffi the significant reduction occurred at 24 and $72 \mathrm{~h}(\mathrm{~F}=53.2, \mathrm{p}<0.0001)$ (Figure 2d). It is noteworthy that the inhibition of infectivity was not observed in human monocytes, as all groups had a high rate of monocyte infection by Leishmania spp.

In the experimental treatment of hamsters, the animals infected with $L$. (L.) amazonensis and left untreated had a higher average weight $(173.33 \mathrm{~g})$ than the average weight in the other groups $(150.16 \mathrm{~g})(\mathrm{p}<0.0001)$. In hamsetrs infected with $L$. (V.) braziliensis, the group treated with Glucantime (average $197.33 \mathrm{~g}$ ) had a higher weight than in the other groups (average $173.45 \mathrm{~g})(\mathrm{p}<0.0001)$. In the groups infected with $L$. (V.) guyanensis, there was no difference among groups in the weight of the animals.

Regarding the clinical evolution of leishmaniasis, there was no significant difference in the volume of the snout among hamster groups infected with $L$. (L.) amazonensis (Figure 3a). The treatment lasted only 25 days due to the lethargic behavior of the animals and the exacerbated evolution of the lesions.

Animals infected with $L$. (V.) guyanensis and $L$. (V.) braziliensis and treated with the copper(I) complex ointment showed a reduction of only $17 \%$ and $18 \%$ in the volume of the snout, respectively, by the end of the 30-day period. There was no significant difference among infected and untreated animals. In the Glucantime group, the volume of the snout was reduced by $73 \%(\mathrm{~F}=75.03, \mathrm{p}<0.0001)$ in $L$. (V.) guyanensis and $70 \%(\mathrm{~F}=11.96, \mathrm{p}<0.0001)$ in $L$. (V) braziliensis, differing from the other treatment groups (Figure 3b,c).

For all Leishmania species, the treatment with either Glucantime or with the copper(I) complex ointment induced a reduction in the volume of the snout after the $15^{\text {th }}$ day of treatment. In all groups infected with $L$. (L.) amazonensis, until the second week of treatment, a gradual increase in the volume of the snout was observed due to the formation of the nodule and edema. After the $15^{\text {th }}$ day, there was a reduction in edema and the beginning of ulceration of the lesions, and the snout volume was larger during the entire experimental period when compared to the groups infected by other species, with ulcerated, exacerbated lesions and the presence of scabs. None of the groups presented clinical cure under any type of treatment (Figure 4a).

All groups infected by L. (V.) guyanensis (Figure 4b) and $L$. (V) braziliensis (Figure 4c) presented nodule formation, but no exacerbated ulceration lesion. The most frequent lesions had scabs. The Glucantime groups achieved $100 \%$ clinical cure at the end of the 30 days of treatment. In the groups treated with copper(I) complex ointment, only $50 \%$ of the animals showed clinical cure with wound healing, but all animals presented snout edema until the $30^{\text {th }}$ day of treatment.

NNN cultures revealed the presence of viable flagellate parasites in the lesion skin and in liver samples in all treatments
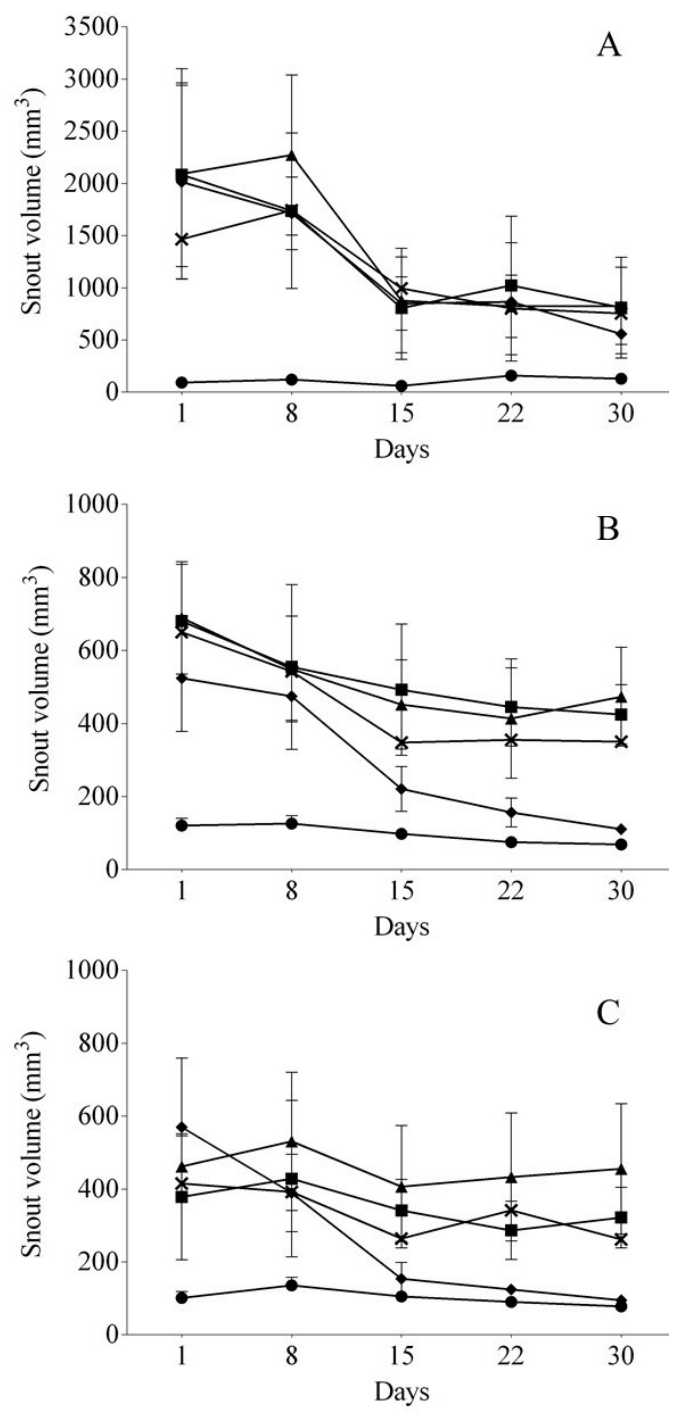

Figure 3. Evolution of the snout volume of hamsters infected with Leishmania (L.) amazonensis (A); L. (V.) guyanensis (B); and L. (V.) braziliensis (C). Uninfected and untreated hamsters (circles), infected and untreated (squares), infected and treated with placebo (triangles), infected and treated intramuscularly with Glucantime ${ }^{\circledast}$ $20 \mathrm{mgSb}^{5} \mathrm{~kg}$ day $^{-1}$ (diamonds) and infected and treated with ointment containing $0.5 \mathrm{mg}$ of copper(I) complex (X-mark).

with all Leishmania species. There was no significant difference in the infectivity rate among treatments in animals infected with $L$. (L.) amazonensis. The animals infected with $L$. (V.) guyanensis and $L .(V$.) braziliensis presented a lower infection rate in the Glucantime treatment when compared to the other treatments $(\mathrm{F}=33.98, \mathrm{p}=0,0006$ and $\mathrm{F}=67.98, \mathrm{p}=$ 0.0013 , respectively) (Figure 5).

There was no significant difference in organ weight (liver, spleen and kidney) and hematological parameters among the experimental groups for any of the tested Leishmania species. 


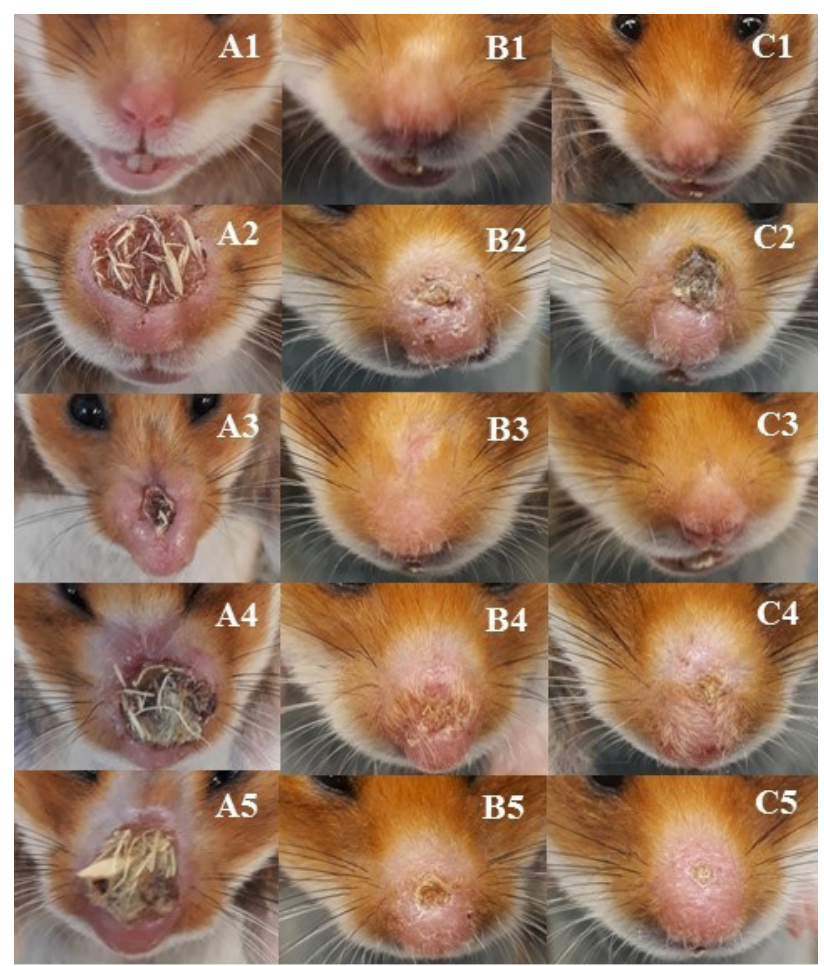

Figure 4. Clinical aspects of the snout lesions of hamsters, Mesocricetus auratus infected by Leishmania (L.) amazonensis (A) on the $25^{\text {th }}$ day of treatment; L. (V.) guyanensis (B) and $L$. (V.) braziliensis (C) on the $30^{\text {th }}$ day of treatment. A1, B1, C1 - uninfected and untreated animals; A2, B2, C2 - infected and untreated animals; A3, B3, C3 - animals infected and treated with Glucantime ${ }^{\circledast}\left(20 \mathrm{mgSb}^{5} \mathrm{~kg}\right.$ day ${ }^{-1}$ intramuscularly); A4, B4, C4 - animals infected and treated with placebo; A5, B5, C5 - animals infected and treated with ointment containing $0.5 \mathrm{mg}$ of copper(I) complex. This figure is in color in the electronic version.

\section{DISCUSSION}

As expected, in the biological cytotoxicity assays, the copper(I) complex showed moderate cytotoxicity and cell viability $\left(>75 \%, \mathrm{CC}_{50}>0.4 \mathrm{mM}\right)$, similar to that observed in the treatment with Glucantime. Similar results were obtained for different copper(II) complexes, with $\mathrm{IC}_{50}$ values of 186.61 $\mu \mathrm{M}$ (Boutaleb-Charki et al. 2009), $558.6 \mu \mathrm{M}$ (Caballero et al. 2014) and $813.5 \mu \mathrm{M}$ in cells of the J774 lineage (MéndezArriaga et al. 2020).

In our tests of antileishmanial activity in vitro, a dosedependent response was observed, in which the highest concentrations of the copper(I) complex (0.16 and 0.08 $\mathrm{mM}$ ) were more effective in inhibiting promastigotes and amastigotes. Similar dose-dependent parasitic inhibition $\left(0.365 \mathrm{mg} \mathrm{mL}^{-1}\right)$ was reported by Hummadi et al. (2005. In the promastigote forms of $L$. (L.) amazonensis, there was no parasitic inhibition, however, the copper(I) complex was more efficient against amastigotes of this species, with a $75 \%$ reduction in the infection rate at 48 and $72 \mathrm{~h}$. Likewise, Maffei et al. (2009) observed a $\mathrm{IC}_{50}$ decline (at 48 and 72 hours)
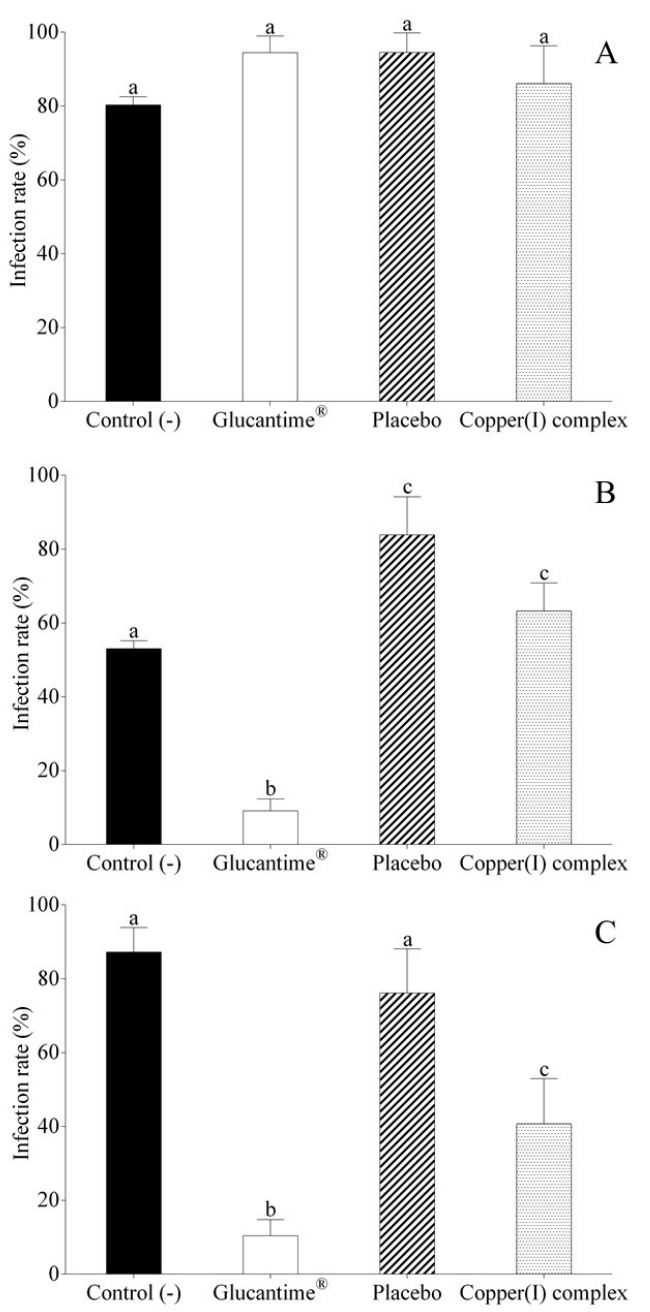

Figure 5. Infection rate via quantification of infected macrophages on the slide print of fragments of lesions from hamsters infected with Leishmania (L.) amazonensis (A); L. (V.) guyanensis (B); and L. (V.) braziliensis (C). Infected and untreated animals (black coluns), animals infected and treated with $20 \mathrm{mgSb}^{5} \mathrm{~kg}$ day $^{-1}$ of Glucantime ${ }^{\oplus}$ (white columns), animals infected and treated with placebo (striped columns), and animals infected and treated with ointment containing 0,5 mg of copper(I) complex (dotted columns). Columns represent the mean and bars the standard deviation. Different letters indicate significant differences according to the Tukey test $(p<0.05)$.

for three copper(II) complexes against $L$. (L.) amazonensis, suggesting a long-term activity for this species.

In the promastigote forms of $L$. (V.) braziliensis, the copper(I) complex inhibited more than $50 \%$ of the promastigote forms, with SI greater than 20 after $72 \mathrm{~h}$ and greater efficacy than Glucantime, while in the amastigote forms, the copper(I) complex decreased the infection rate by at least $75 \%$, with similar efficacy to Glucantime. These results corroborate those of Caballero et al. (2014), who showed that copper(II) complexes had similar toxicity to Glucantime in the promastigote and amastigote forms of $L$. (V.) braziliensis, 
and a SI higher than 54.2 after $72 \mathrm{~h}$. Other studies, such as those of Méndez-Arriaga et al. (2018) and Méndez-Arriaga et al. (2020), also reported the activity of copper(II) complexes in L. (V.) braziliensis, with $\mathrm{IC}_{50}$ of $100.2 \mu \mathrm{M}$ (IS 14.5) and 42.6 $\mu \mathrm{M}$ (IS 19.1), respectively.

To the best of our knowledge, there are no published studies on the antileishmanial activity of metal complexes for L. (V.) guyanensis and L. (V.) naiffi. Our results indicate that the copper(I) complex is efficacious against promastigote forms of these species. This is also the first report of the antileishmanial effects of a copper complex in a preclinical study with animals.

Currently there is no information available in the literature regarding the topical experimental treatment of leishmaniasis with metal complexes. The drugs currently used to treat cutaneous leishmaniasis are administered parenterally and have serious adverse effects. In this sense, topical administration of medications for leishmaniasis may be an interesting option, since the use of topical medications allows the concentration of the active ingredient in the site of infection. It offers a possible decrease in toxicity and, because it is not invasive, the treatment can be done outside the hospital environment (Bocxlaer et al. 2018). In addition, topical treatment can also be used together with other drugs, thus potentiating and reducing the time of treatment of the disease. Due to the lipophilic characteristics of the copper(I) complex, the use of hydrophobic ointments is an attractive alternative, since they have an emollient effect, are difficult to remove, do not become dry and, in addition, allow the drug to remain in prolonged contact with the skin and act as an occlusive dressing (Otto et al. 2018).

Another relevant factor for the development of a topical formulation is related to intoxication by metals because, although copper is an essential element for several physiological and biochemical functions, it is also related to diseases caused by the abundance and deficiency of this metal in the body. As such, it is necessary to stipulate doses for treatment that take into consideration the essential daily concentrations. In an adult man, these can vary from 0.9 to $2.2 \mathrm{mg}$ (Baierle et al. 2010), although its topical use has a different effect in terms of absorption by the body, differently than if it were administered parenterally.

None of our treatments with the copper(I) complex achieved the clinical cure (total healing and reepithelization of the skin) and parasitological cure (the complete elimination of the parasite) of the animals infected with $L$. ( L.) amazonensis. In animals infected with $L$. (V.) guyanensis and L. (V.) braziliensis, the copper(I) complex ointment induced a reduction in lesion volume, but clinical cure was achieved only in $50 \%$ of the infected animals, and no parasitological cure was observed. In contrast, animals treated with Glucantime achieved $100 \%$ clinical cure, but also no parasitological cure, which had already been demonstrated in humans (MartínezValencia et al. 2017).

Although several in vitro studies with metal complexes have been developed in the search for new alternative treatments for cutaneous leishmaniasis, few have evaluated the effects in vivo. Among them, the study by Nascimento et al. (2019) suggested a promising leishmanicidal effect of the ruthenium nitrosil complex $\left(300 \mu \mathrm{g} \mathrm{kg} \mathrm{day}{ }^{-1}\right.$ through oral administration) against $L$. (V.) braziliensis in a model of skin infection in vivo (hamster), obtaining a $51 \%$ reduction in lesion size and $99.9 \%$ elimination of parasites. These authors did not observe toxic reactions to the metal complex, nor changes in size, weight and appearance of organs, or in the leukogram of test animals, which is corroborates in our study.

Our results encourage further studies that evaluate the effectiveness of the copper(I) complex in a new formulation and a new experimental treatment scheme, with emphasis on the effectiveness of the skin permeation issue, animal experimentation model, species of Leishmania involved, concentrations of the active principle and treatment time. Further research is recommended using different concentrations, formulations, routes of administration, and treatment time using the copper(I) complex, and it is also necessary to elucidate the therapeutic mechanism and the toxicological aspects.

\section{CONCLUSIONS}

The copper(I) complex showed promising in vitro activity against the evolutionary forms of Leishmania (V.) braziliensis. In the pre-clinical study, there was a reduction of about $17 \%$ and $18 \%$ in the size of skin lesions in animals infected with parasites of the sub-genus Viannia, species L. (V.) guyanensis and $L$. (V.) braziliensis respectively, treated topically with the ointment containing the copper(I) complex. It is suggested that the ointment be used in conjunction with other drugs for parasitic infections by the subgenus Viannia.

\section{ACKNOWLEDGMENTS}

The authors would like to thank Coordenação de Aperfeiçoamento de Pessoal de Nível Superior - CAPES, PhD. Francesco Tisato, MSc. Maricleide de Farias Naiff and technician Lorival Maciel Castro.

\section{REFERENCES}

Arndt, A; Liria, C.W.; Yokoyama-Yasunaka, J.K.U.; Manchini, M.T.; Uliana, S.R.B.; Espósito, B.P. 2017. New iminodibenzyl derivatives with anti-leishmanial activity. Journal of Inorganic Biochemistry, 172: 9-15.

Baierle, M.; Valentini, J.; Paniz, C.; Moro, A.; Barbosa Junior, F.; Garcia, S.J. 2010. Possíveis efeitos do cobre sanguíneo sobre parâmetros hematológicos em idosas. Jornal Brasileiro de Patologia e Medicina Laboratoria,1 46: 463-479. 
Bastos, M.M.; Boechat, N.; Hoelz, L.V.B.; Oliveira, A.P. 2016. Quimioterapia antileishmania: Uma revisão bibliográfica. Revista Virtual de Quimica, 6: 2072-2104.

Blanco, V.R.; Nascimento-Júnior, NM. 2017. Leishmaniose: Aspectos gerais relacionados com a doença, o ciclo do parasita, fármacos disponíveis, novos protótipos e vacinas. 2017. Revista Virtual de Química, 9: 861-876.

Bocxlaer, K.V.; Gaukel, E.; Hauser, D.; Park, S.H.; Schock, S.; Yardley, V.; et al. 2018. Topical treatment for cutaneous leishmaniasis: Dermatopharmacokinetic lead optimization of benzoxaboroles. Antimicrobial Agents and Chemotherapy, 62 :e02419-17.

Boutaleb-Charki, S.; Marín, C.; Maldonado, C.R.; Rosales, M.J.; Urbano, J.; Guitierrez-Sánchez, R.; Quirós, M.; Salas, J.M.; Sánchez-Moreno, M. 2009. Copper(II) complexes effects potential anti-parasitic agents. Drug Metabolism Letters, 3: 35-44.

Brasil. 2017. Manual de Vigilância da Leishmaniose Tegumentar Americana. Ministério da Saúde, Secretaria de Vigilância em Saúde, Brasília, 189p. (https://bvsms.saude.gov.br/bvs/ publicacoes/manual_vigilancia_leishmaniose_tegumentar.pdf). Accessed on 30 Jun 2021.

Bruschi, F.; Gradoni, L. 2018. The Leishmaniasis: Old Neglected Tropical Diseases, 1st ed. Springer International Publishing, New York, 245p.

Caballero, A.B.; Rodríguez-Diéguez, A.; Quirós, M.; Salas, J.M.; Huerta, O.; Ramírez-Macías, I.; et al. 2014. Triazolopyrimidine compounds containing first-row transition metals and their activity against the neglected infectious Chagas disease and leishmaniasis. European Journal of Medicinal Chemistry, 85: 526-534.

Comandolli-Wyrepkowski, C.D.; Jensen, B.B.; Grafova, I.; Santos, P.A.; Barros, A.M.C.; Soares, F.V.; Barcellos, J.F.M.; Silva, A.L.; Grafov, A.; Franco, A.M.R. 2017. Antileishmanial activity of extracts from Libidibia ferrea: development of in vitro and in vivo tests. Acta Amazonica, 47: 331-340.

Gandin, V.; Tisato, F.; Dolmella, A.; Santini, M.P.; Santini, C.; Giorgetti, M.; Marzano, C.; Porchia, M. 2014. In vitro and in vivo anticancer activity of copper(I) complexes with homoscorpionate tridentate tris(pyrazolyl)borate and auxiliary monodentate phosphine ligands. Journal of Medicinal Chemistry, 57: 4745-4760.

Hummadi, Y.M.A.L.; Najim, R.A.; Al-Bashi, N. 2005 Leishmania major and Leishmania tropica: I the in vitro effects of an immunomodulator, S2-Complex. Experimental Parasitology, 111: 47-54.

Hussain, A.; Alajmi, M.F.; Rehman, M.T.; Amir, S.; Hussain, F.M.; Alsalme, A.; Siddiqui, M.A.; Alkhedhairy, A.A.; Khan, R.A. 2019. Copper(II) complexes as potential anticancer and nonsteroidal anti-inflammatory agents: In vitro and in vivo studies. Scientific Reports, 9: 1-17. doi.org/10.1038/s41598019-41063-x.

Keighobadi, M.; Akhtari, J.; Fakhar, M.; Emami, S.; Mirzaei, H. 2018. An overview on anticancer drugs with antileishmanial activity. Journal of Mazandaran University of Medical Sciences, 28: 154-165.
Krupanidhi, S.; Sreekumar, A.; Sanjeevi, C.B. 2008. Copper \& biological health. Indian Journal of Medical Research, 128: 448-461.

Maffei, R.S.; Yokoyama-Yasunaka, J.K.U.; Miguel, D.C.; Uliana, S.R.B.; Espósito, B.P. 2009. Synthesis, characterization and evaluation of antileishmanial activity of copper(II) with fluorinated a-hydroxycarboxylate ligands. Biometals, 22: 1095-1101.

Martínez-Valencia, A.J.; Daza-Rivera, C.F.; Rosales-Chimala, M.; Cossio, A.; Ricón, E.J.C.; Desai, M.M.; Saraiva, G.N.; Gómez, M.A. 2017. Clinical and parasitological factors in parasite persistence after treatment and clinical cure of cutaneous leishmaniasis. Plos Neglected Tropical Disease, 11: e0005713.

Méndez-Arriaga, J.M.; Oyarzabal, I.; Escolano, G.; RodríguezDieguez, A.; Sánchez-Moreno, M.; Salas, J.M. 2018. In vitro leishmanicidal and trypanocidal evaluation and magnetic properties of 7-amino-1,2,4- triazolo[1,5-a]pyrimidine $\mathrm{Cu}(\mathrm{II})$ complexes. Journal of Inorganic Biochemistry, 180: 26-32.

Méndez-Arriaga, J.M.; Rodríguez-Diéguez, A.; Sánchez-Moreno, M. 2020. In vitro leishmanicidal activity of copper(II) 5,7-dimethyl1,2,4-triazolo[1,2,4]Triazolo [1,5-a]Pyrimidine Derivatives as [1,5-a]pyrimidine complex and analogous transition metal series. Polyhedron, 176: 1-6. doi.org/10.1016/j.poly.2019.114272.

Nascimento, N.R.F.; De Aguiar, F.L.N.; Santos, C.F.; Luna Costa, A.M.; De Jesus Hardoim, D.; Da Silva Calabrese, K.; Gadelha Rocha, M.F. 2019. In vitro and in vivo leishmanicidal activity of a ruthenium nitrosyl complex against Leishmania (Viannia) braziliensis. Acta Tropica, 196: 61-65.

Navarro, M.; Cisneros-Fajardo, E.J.; Fernandez-Mestre, M.; Arrieche, D.; Marchan, E. 2003. Synthesis, characterization, DNA binding study and biological activity against. Journal of Inorganic Biochemistry, 97: 364-369.

Ong, Y.C.; Roy, S.; Andrews, P.C.; Gasser, G. 2019. Metal compounds against neglected tropical diseases. Chemical Reviews, 119: 730-796.

Otto, V.; França, F.; Horfler, R. 2018. Formas farmacêuticas semissólidas para tratamento tópico. Fármaco Terapêutica, 2: 3-9.

Porchia, M.; Tisato, F.; Zancato, M.; Gandin, V.; Marzano, C. 2020 In vitro antitumor activity of water-soluble copper(I) complexes with diimine and monodentate phosphine ligands. Arabian Journal of Chemistry, 13: 998-1010.

Portas, A.S.; Miguel, D.C.; Yokoyama-Yasunaka, J.K.U.; Uliana, S.R.B.; Espósito, B.P. 2012. Increasing the activity of copper(II) complexes against Leishmania through lipophilicity and prooxidant ability. Journal of Biological Inorganic Chemistry, 17: 107-112.

Saeed, A.; Larik, F.A.; Jabeen, F.; Mehfooz, H.; Ghumro, S.A.; ElSeedi, H.R.; Ali, M.; Channar, P.A.; Ashraf, H. 2018. Synthesis, antibacterial and antileishmanial activity, cytotoxicity, and molecular docking of new heteroleptic copper(I) complexes with thiourea ligands and triphenylphosphine. Russian Journal of General Chemistry, 88: 541-550.

Tapanelli, S.; Habluetzel, A.; Pellei, M.; Marchiò, L.; Tombesi, A.; Capparè, A.; Santini, C. 2017. Novel metalloantimalarials: Transmission blocking effects of water soluble $\mathrm{Cu}(\mathrm{I}), \mathrm{Ag}(\mathrm{I})$ and $\mathrm{Au}(\mathrm{I})$ phosphane complexes on the murine malaria parasite 
Plasmodium berghei. Journal of Inorganic Biochemistry, 166: 1-4. doi.org/10.1016/j.jinorgbio.2016.10.004.

Teles, C.B.G.; Santos, A.P.A.; Freitas, R.A.; Oliveira, A.F.J.; Ogawa, G.M.; Rodrigues, M.S.; Pessoa, F.A.C.; Medeiros, J.F.; Camargo, L.M.A. 2016. Phlebotomine sandly (Diptera: Psychodidae) diversity and their Leishmania DNA in a hot spot of American Cutaneous Leishmaniasis human cases along the Brazilian with Peru and Bolívia. Memórias do Instituto Oswaldo Cruz, 111: 423-432.

Tisato, F.; Marzano, C.; Peruzzo, V.; Tegoni, M.; Giorgetti, M.; Damjanovic, M.; Trapananti, A.; Bagno, A.; Santini, C.; Pellei, M.; et al. 2016. Insights into the cytotoxic activity of the phosphane copper(I) complex $\left[\mathrm{Cu}(\mathrm{thp})_{4}\right]\left[\mathrm{PF}_{6}\right]$. Journal of Inorganic Biochemistry, 165: 80-91.

WHO. 2021. World Health Organization. Leishmaniasis. (https:// www.who.int/health-topics/leishmaniasis\#tab=tab_1). Acessed on 22 Feb 2021.

RECEIVED: $22 / 03 / 2021$

ACCEPTED: $19 / 06 / 2021$

ASSOCIATE EDITOR: Waldireny C. Rocha 